\title{
Genetic and demographic responses of fragmented Acacia dealbata (Mimosaceae) populations in southeastern Australia
}

\author{
Linda M. Broadhurst*, Andrew G. Young, Robert Forrester \\ CSIRO Plant Industry, P.O. Box 1600, Canberra, ACT 2601, Australia
}

\section{A R T I C L E I N F O}

Article history:

Received 12 May 2008

Received in revised form

11 August 2008

Accepted 16 August 2008

Available online 26 September 2008

Keywords:

Fragmentation

Acacia

Population genetics

Fitness

Persistence

Mating system

\begin{abstract}
A B S T R A C T
Genetic and demographic studies of fragmented populations of common plant species often reveal negative impacts that are likely to constrain persistence. Examining species that are broadly representative of functional groups within fragmented landscapes is one approach to providing a better understanding of how these processes will influence vegetation persistence. Acacias are a significant component of the Australian flora, with Acacia dealbata being a common and representative species of fragmented landscapes across New South Wales. Previous reproductive assessments of fragmented A. dealbata populations indicated significant constraints for small populations through low reproductive output mediated by fertilisation success. This study examined genetic diversity, mating system, and progeny growth parameters of the seed crops produced by these populations to assess whether further constraints to persistence could be detected. Spatially explicit simulation studies were also conducted to assess the persistence likelihood of fragmented populations. Landscape parameters such as population size and plant density were useful predictors for some of the genetic and demographic responses, but a poor response signal was generally observed. Strong evidence for a self-incompatibility mechanism was observed in A. dealbata and is likely to be the major driver of population persistence. Self-incompatibility in small populations limits mate availability and eliminates inbred progeny early in the reproductive cycle leading to poor reproductive output. The simulation data provides further evidence that mate limitation in smaller populations (<200 plants and $40 \mathrm{~S}$ alleles) constrains reproductive output and persistence. These data indicate that introducing new germplasm to smaller populations can dramatically improve their persistence likelihood.

Crown Copyright $\odot 2008$ Published by Elsevier Ltd. All rights reserved.
\end{abstract}

\section{Introduction}

Habitat destruction remains one of the most threatening processes for plant population persistence on a worldwide basis. Many studies now highlight how changes in habitat configuration and abundance negatively impact on the demographic and genetic processes that sustained previously continuous vegetation (Aguilar and Galetto, 2004; Buza et al., 2000; Donaldson et al., 2002; Groom, 2001; Tomimatsu and Ohara, 2003; Vergeer et al., 2003; Young et al., 2000). Of further concern are the flow-on effects to mutualistic associations, such as pollination and dispersal, that these disruptions produce (Agren, 1996; Kolb, 2005; Rodriguez-Cabal et al., 2007; Ward and Johnson, 2005). Accordingly, the capacity of many remnant populations to remain as self-sustaining and functional landscape elements over longer time frames is being seriously eroded (see Lienert (2004) for review). Given the importance of remnant vegetation in the provision of ecosystem services and biodiversity values in highly modified and degraded environments, it is clear that

* Corresponding author: Tel.: +61 26246 4988; fax: +61 262465000.

E-mail address: Linda.Broadhurst@csiro.au (L.M. Broadhurst).

0006-3207/\$ - see front matter Crown Copyright @ 2008 Published by Elsevier Ltd. All rights reserved.

doi:10.1016/j.biocon.2008.08.021 
careful management is required to ensure their long-term sustainability.

Successful management of remnant vegetation requires an understanding of the contribution that genetic and demographic processes have to maintaining functional vegetation in the landscape. More importantly, it requires the development of strategies that will not only support and sustain populations, but will also mitigate against those processes likely to effect decline. A large body of evidence has developed over the past three decades that has identified numerous constraints to plant population persistence including reproductive strategy (Aizen and Feinsinger, 1994), reduced population sizes and increased isolation (Paschke et al., 2002; Prober and Brown, 1994; White et al., 1999; Young et al., 1999), pollinator limitation (Agren, 1996; Kolb, 2005; Ward and Johnson, 2005), mate availability (Jacquemyn et al., 2003; Young et al., 2000) and dispersal (Garcia and Chacoff, 2007). Most of these studies are of rare herbaceous taxa that present unequivocal evidence of constraints to persistence (Buza et al., 2000; Groom, 2001; Luijten et al., 2000; Young et al., 2000). Similar studies for common and widespread species are showing similar effects with a recent meta-analysis indicating that abundant taxa may as vulnerable to fragmentation effects as rare taxa (Honnay and Jacquemyn, 2007). Many studies of abundant taxa, however, derive data from herbs (Hooftman et al., 2004; van Rossum et al., 2004) and tropical trees (Aldrich et al., 1998; White et al., 1999, 2002), with a relatively recent emphasis on fragmentation effects for temperate shrubs and trees (Bacles et al., 2004; Byrne et al., 2008; Cunningham, 2000; Krauss et al., 2007; Prober and Brown, 1994; Sork et al., 2002; Yates et al., 2007).

Trees and shrubs dominate many vegetation communities across Australia, and in the southeast many woodland and grassy woodland communities have been extensively cleared for agriculture. This broadscale loss of vegetation is now seriously impacting on the biodiversity value of the remaining communities and the ecosystem services that these provide (Australian State of the Environment Committee, 2001; Williams, 2000). While broad predictions as to the response of species to fragmentation can be made for suites of taxa (Broadhurst and Young, 2007), more information is required to not only refine these predictions, but to determine whether leverage points exist where management can make a major impact on ensuring population persistence. Since it is impossible to examine all common plant species, a more strategic approach is to use surrogate species that represent important functional elements in the landscape. In Australia, acacias (Mimosaceae) represent one such functional group, being extremely abundant, widely distributed, and important colonisers recruiting from soil seed stores following disturbance events such as fire (Auld, 1986; Brown et al., 2003). Acacias also support a vast array of insect species (Bernhardt, 1989), are food and habitat resources for vertebrates (Sharpe and Goldingay, 1998; Thums et al., 2005), and form symbiotic relationships with nitrogen-fixing soil micro-organisms. This latter association is highly advantageous in nutritionally poor Australian soils where the nitrogen fixed benefits both acacias and co-occurring non-leguminous species (Khanna, 1997). Prolific acacia flowering characterises many southern Australian vegetation communities from late winter to mid spring
(Bernhardt, 1989), and in fragmented landscapes these impressive floral displays can be readily misinterpreted as positive indications of population health and persistence. Despite being such a prevalent and important component of Australian plant communities, little is directly known as to whether fragmentation is impacting on demographic and genetic processes within Acacia populations. If so, the decline of this genus is likely to have significant effects on the long-term future of natural vegetation cover across Australia (Broadhurst and Young, 2007).

The results reported here are part of a larger study to assess potential demographic and genetic constraints on fragmented species across the southern tablelands of New South Wales (Young et al., 2005). The study species, Acacia dealbata, is a common component of grassy woodlands in southeastern Australia and a companion study that assessed two years of reproductive output for eleven populations representing the range of fragmented remnants present identified fertilisation success as a major constraint to the persistence of small populations (Broadhurst and Young, 2006). We used seed crops collected during this study to determine whether other genetic or demographic constraints to population persistence exist. We assessed various genetic, mating system, and growth parameters, and related these responses to landscape variables previously generated for each of the study populations (Broadhurst and Young, 2006). More specifically we were interested in answering the following questions: (i) are similar levels of genetic diversity being generated by the populations?, (ii) what is the breeding system of A. dealbata, and do breeding system estimates vary among the populations?, (iii) does progeny growth reflect variation in the genetic diversity and mating system estimates generated? and, (iv) are associations evident between the breeding system, genetic diversity and progeny growth responses, and landscape variables such as population size and isolation? We also used these data and demographic information on acacias from the scientific literature to model various scenarios for population persistence under a gametophytic selfincompatibility system to determine the demographic limits that this kind of mating system may place on remnant populations. We also modelled the potential for population recovery and persistence under genetic versus demographic management practices.

\section{Materials and methods}

\subsection{Study region, species background and site characterisation}

The southern tablelands of New South Wales are located in southeastern Australia where much of the region is elevated (500-700 m) with a mountain range to $1000 \mathrm{~m}$ in the southwest. Vegetation across the region has been extensively cleared in the $\sim 150$ years since European settlement resulting in significant losses of biodiversity. Only $13 \%$ of the estimated $45 \%$ of the region that supported grassy ecosystems prior to settlement remains, most of which is now highly modified and degraded (ACT Government, 2004) with the remaining natural temperate grasslands and several woodland communities being formally protected (see Prober et al. (2002) for 
details). Remnant vegetation patterns vary across the region, but this study was conducted in areas where vegetation loss is as high as 95\% (ACT Government, 2004), and fragmentation patterns correspond with McIntyre and Hobbs (1999) fragmented and relictual remnant classifications.

Grassy woodlands across the southern tablelands are typified by an open, eucalypt-dominated canopy, with a sparse shrub layer and diverse ground cover of tussock grasses and herbs. A. dealbata (silver wattle) is one of many acacias found in these communities and is a bushy shrub or tree growing to $30 \mathrm{~m}$ (Maslin, 2001). It is moderately long-lived (20-50 years), produces bright yellow racemes from winter to spring, is an important vertebrate food source (Smith, 1984), nitrogen-fixer (Adams and Attiwill, 1984; Hopmans et al., 1983), and adds structural complexity to grassy woodland communities. Little is known regarding the reproductive ecology or genetics of this species. It is likely that A. dealbata produces a soil seed bank while field observations indicate that severe damage or senescence can induce suckering. Plants in this study were spatially sampled to preclude the possibility of collecting identical genotypes. A. dealbata may also be self-incompatible since studies of sexually reproducing acacias indicate that these are self-incompatible and likely to be controlled by a gametophytic mechanism (Casiva et al., 2004; Kenrick et al., 1986; Kenrick and Knox, 1989b; McGranahan et al., 1997).

For this study 14 populations, including the eleven in the companion study (Broadhurst and Young, 2006), representing the range of remnant fragmentation across the southern tablelands were selected (Fig. 1). Fragmentation status was assessed at each site using five landscape variables - population size and density, isolation, the total number of species at each site which were directly measured, and the ratio of native to exotic species at each site which was calculated as a surrogate measure of remnant integrity (Table 1). These measures are described in more detail in Broadhurst and Young (2006). Seed were collected from each population from 1 to 20 plants in 2002 and 2003 to generate mating system, genetic diversity and seedling growth estimates (Table 1) from $5 \times 30 \mathrm{~cm} \mathrm{sec}-$ tions of branch around the canopy of each tree. When seed set was low, collections were augmented by further sampling from around plant canopies, and in larger sites, collections from other plants haphazardly chosen across the site. This study coincided with the beginning of one of the worst droughts recorded across southeastern Australian, and while reproductive output was assessed for a several trees in each population, not all of these trees produced enough seed for all of the experiments in this study (Table 1).

\subsection{Genetic diversity}

Seed were surface sterilised ( $2 \%$ sodium hypochlorite for $4 \mathrm{~min}$ ), rinsed and the testa nicked prior to all experiments. For the genetic studies, the seed were germinated in petri dishes at room temperature. In most populations 2-3 seed were randomly selected from each tree and germinated, although for some of the smaller sites, more progeny from each tree were used to capture as much genetic diversity as possible. It must be remembered, however, that this data is based on relatively few trees within these sites. Seedlings (1-3 days) were individually ground in 3-4 drops of extraction buffer, and subjected to horizontal starch gel electrophoresis as described by Young et al. (1999). Seven enzyme systems

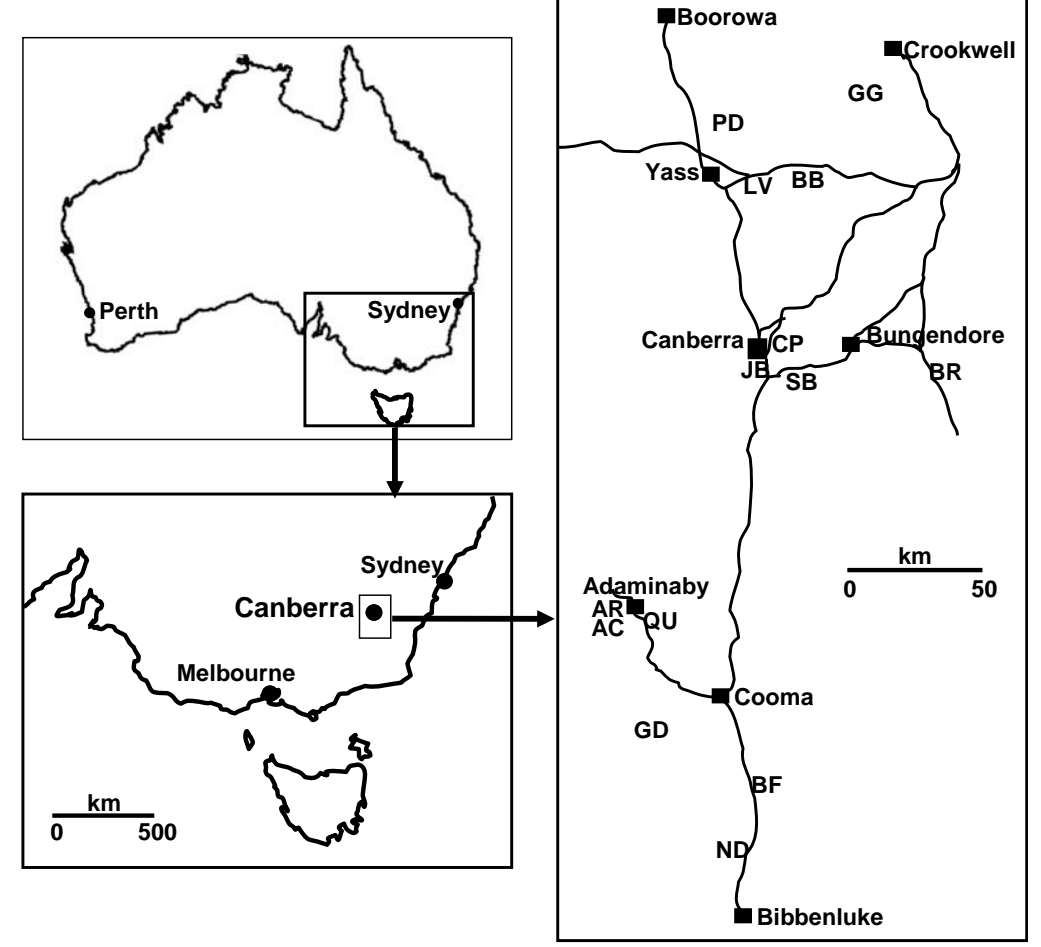

Fig. 1 - Acacia dealbata study populations across the southern tablelands of New South Wales, Australia. Population codes are in Table 1. 
Table 1 - Site characteristics and sampling strategy for Acacia dealbata genetic and growth experiments

\begin{tabular}{|c|c|c|c|c|c|c|c|c|c|c|c|}
\hline \multirow[t]{2}{*}{ Population } & \multirow[t]{2}{*}{ Code } & \multirow[t]{2}{*}{ Size } & \multicolumn{3}{|c|}{ Remnant characteristics } & \multicolumn{6}{|c|}{ No. of mothers sampled } \\
\hline & & & $\begin{array}{c}\text { Density } \\
\text { (plant } \\
\mathrm{ha}^{-1} \text { ) }\end{array}$ & $\begin{array}{l}\text { Isolation } \\
(\mathrm{km})\end{array}$ & $\begin{array}{c}\text { No. } \\
\text { species }\end{array}$ & $\begin{array}{l}\text { Remnant } \\
\text { integrity }\end{array}$ & $\begin{array}{l}\text { Reproductive } \\
\text { output }\end{array}$ & $\begin{array}{l}\text { Genetic } \\
\text { diversity }\end{array}$ & $\begin{array}{l}\text { Mating } \\
\text { system }\end{array}$ & $\begin{array}{c}\text { Growth } \\
2002\end{array}$ & $\begin{array}{c}\text { Growth } \\
2003\end{array}$ \\
\hline Adaminaby cemetery & AC & 1 & 1 & 1.57 & 68 & 1.72 & $1(1)$ & 1 & & - & 1 \\
\hline Jerrabomberra & JB & 3 & 6 & 2.22 & 60 & 1.86 & 2(3) & 1 & & & \\
\hline Campbell park & $\mathrm{CP}$ & 3 & 6 & 0.50 & 51 & 0.82 & $2(2)$ & 1 & & & \\
\hline Native dog & ND & 4 & 2 & 2.40 & 98 & 2.38 & $2(4)$ & 2 & & & \\
\hline Braidwood & $\mathrm{BR}$ & 13 & 1 & 0.50 & 86 & 1.69 & - & 3 & & & \\
\hline Berrabangalo & BB & 15 & 1 & 1.20 & 65 & 1.96 & - & 6 & 5 & 2 & 2 \\
\hline Adaminaby road & AR & 17 & 17 & 1.10 & 57 & 1.85 & $7(7)$ & 6 & 5 & 5 & - \\
\hline Gydzderick & GD & 18 & 9 & 1.22 & 83 & 1.24 & 10(9) & 6 & & 1 & 2 \\
\hline Lade vale & LV & 33 & 8 & 0.87 & 39 & 0.95 & $10(10)$ & 9 & 6 & 5 & 10 \\
\hline Black flat & $\mathrm{BF}$ & 38 & 1 & 2.41 & 95 & 2.39 & $10(11)$ & 3 & & - & 4 \\
\hline Scabbing flat & SB & 90 & 5 & 0.70 & 98 & 3.46 & - & 6 & & & \\
\hline Grabben Gullen & GG & 138 & 9 & 0.44 & 100 & 2.03 & $12(14)$ & 12 & 10 & 9 & 3 \\
\hline Pudmans & $\mathrm{PD}$ & 212 & 9 & 1.28 & 110 & 4.50 & $15(14)$ & 20 & 11 & 10 & 13 \\
\hline Queensgallery & QU & 1674 & 44 & 0.26 & 74 & 3.11 & 19(19) & 17 & 11 & 7 & 14 \\
\hline
\end{tabular}

encoded by 13 putative loci were resolved using three buffer systems; (i) glucose-6-phosphate isomerase (GPI) E.C. 5.3.1.9 (1 locus), aspartate aminotransferase (AAT) E.C. 2.6.1.1 (4 loci) and menandione reductase (MDR) E.C. 1.6.99 (3 loci) in a lithium-borate pH 8.5 buffer system, (ii) glucose-1-phosphate uridyl transferase (GPUT) E.C. 2.7.7.9 (2 loci) and phosphoglucomutase (PGM) E.C. 5.4.2.2 (1 locus) in a morpholine citrate (MC) pH 6.1 buffer, and (iii) isocitric dehydrogenase (IDH) E.C. 1.1.1.42 (1 locus) and phosphogluconic dehydrogenase (PGD) E.C. 1.1.1.44 (1 locus) in a Tris-maleate pH 7.4 buffer. Single locus diversity measures generated using the 13 loci included the number of alleles per locus $(A)$, number of alleles per polymorphic loci $\left(A_{P}\right)$, percentage of polymorphic loci per population ( $P$, criterion $95 \%$ ), observed heterozygosity $\left(H_{\circ}\right)$, gene diversity (expected panmictic heterozygosity, $H_{e}$ ), fixation coefficient $\left(F_{I S}\right)$ and number of private alleles $[p(1)]$. All analyses were conducted using GENETIC DATA ANALYSIS (GDA) version 1.1 (Lewis and Zaykin, 2001).

\subsection{Mating system and genotype diversity}

Progeny arrays (11-20 seed) were available from six populations for mating system analyses (Table 1). Six loci were polymorphic at Lade Vale, seven at Adaminaby Road and nine at Berrabangalo, Grabben Gullen, Queensgallery and Pudmans. Maximum likelihood estimates of single- $\left(t_{s}\right)$ and multi-locus $\left(t_{m}\right)$ outcrossing rates were calculated following the mixedmating model with maternal genotypes being inferred from progeny arrays (Brown and Allard, 1970) and $t_{m}-t_{s}$ was used as an estimate of mating between close relatives (biparental inbreeding). Correlation of outcrossed paternity $\left(r_{p}\right)$ was estimated following Ritland (1989) sibling-pair model in which $r_{\mathrm{p}}$ is the probability that two individuals drawn at random from the same progeny array are full-sibs. All of these parameters were calculated using the EM algorithm in the MLTR version 3.0 computer program (Ritland, 1990, 2002) with standard deviations generated from 500 bootstraps and resampling among maternal plants. Multilocus progeny genotypes were generated using ten loci that could be resolved across all populations and used to calculate the number of genotypes $(G)$ for each population. Genotype diversity, which is the number of genotypes divided by the number of individuals sampled $(G / n)$, was also calculated as was the proportion of progeny with genotypes found only within a population (G-unique). To test whether the results observed were due to a sampling effect associated with differences in the number of trees sampled for each population, five trees were randomly selected from Lade Vale, Grabben Gullen, Pudmans and Queensgallery to correspond with the number assessed for Adaminaby Road and Berrabangalo, and $G / n$ and $G$-unique recalculated. This procedure was repeated five times for each population.

\subsection{Growth trial}

Seed from 88 trees across nine populations for both study years were available to assess progeny growth (Table 1). Ten seed from each tree were weighed, pre-treated as described above and imbibed in water overnight. Seed were individually planted into $8 \mathrm{~cm}$ pots (1:1:1 peat moss:sand:compost mix with half strength slow release fertilizer formulated for Australian native plants) in a row/column design comprised of two blocks with one replicate of 5 pots for each tree in each block. Pots were maintained under glasshouse conditions for 24 weeks. Germination and survival were checked daily for two weeks, then weekly for the remainder of the trial to provide a measure of final germination percentage (\%Germination), the number of days to germination and germinant survival (Survival). Germination differences between years and among populations were assessed using the number of seed emerging from each of the 5 pot replicates. Since the proportion of seed germinating was likely to follow a Binomial distribution, and due to the nature of the design where there were several strata of variability, a Generalized Linear Mixed Model was fitted to the data using a random model 
of rep/(row + column) and a fixed model of year + population, following removal of Adaminaby Cemetery for which the seedlings were progeny from a single tree in a single year.

Plant height and number of phyllodes were measured at weeks 16 (Height 1 and Phyllode 1) and 24 (Height 2 and Phyllode 2). At harvest, plants were divided into stem (Shoot) and root (Root) components which were dried and weighed following root washing, and used to calculate the shoot to root ratio (Shoot:root). All data were checked for heteroscedacity and skewness and transformations were not required. Due to the unbalanced nature of the growth trial with respect to the number of trees within populations and between years, a mixed model approach using the restricted maximum likelihood structure method (REML) was applied to assess variability among populations and between years with year, population and their interaction as fixed effects, and replicate, row, column and their interactions as random effects. Associations between seed weight and growth responses were assessed separately for each year by single linear regressions using GENSTAT. In addition, linear regressions were used to test for associations between the mating system and genetic diversity estimates and growth responses for 2002 only as no genetic estimates were generated using 2003 seed.

\subsection{Landscape influences on mating system, genetic diversity and growth}

Associations between the five landscape variables (Table 1) and the genetic and growth responses were assessed by single linear regressions using GENSTAT. For those growth responses where two years of data were available, each year was assessed separately.

\subsection{Simulated effects of a gametophytic self- incompatibility system on population persistence}

The effects of gametophytic self-incompatibility system on long-term population viability were examined using an individual-based simulation model described in Hoebee et al. (2008) that includes both genetic and demographic parameters. The model is spatially explicit, being based on a two dimension $(100 \times 100)$ array which was used to simulate a 1 ha patch of A. dealbata population, with each grid representing $1 \mathrm{~m}^{2}$. It assumes no mutation, immigration or inbreeding depression and allows for the number of self-incompatibility alleles ( $S$ alleles) and the number of reproductive plants to vary independently. A fraction of the array cells are available for occupation and at the beginning of each simulation plants whose ages have been randomly assigned according to a log normal distribution with user defined mean and variance are randomly 'seeded' into a subset of these 'safe sites'. Individual genotypes for the $S$ locus are then randomly generated under the provision that initially all plants are heterozygous as predicted at equilibrium under negative frequency dependent selection and generally observed empirically (de Nettancourt, 1997). At each time interval pollen is randomly drawn from the population and allowed to fertilise ovules depending on the compatibility relationships of the randomly paired mates. Seed generated from compatible pollinations are then dispersed. Rates of germination, seedling establishment, growth, flowering and mortality are all user defined.

Given that few genetic and demographic data exist specifically for A. dealbata the literature was reviewed to parameterise the model. While this use of general Acacia ecological data places constraints on analysis of the model output we believe that the parameterisation is biologically realistic enough to produce ecologically valid results if interpreted cautiously. A gametophytic self-incompatibility mechanism was assumed for A. dealbata since Kenrick et al. (1986) observed pollen tube arrest in the nucellus of $A$. retinoides and was proposed as the mechanism to explain self-incompatibility in several other acacias (Kenrick and Knox, 1989b). Given that there is no evidence that self-incompatibility mechanisms have evolved more than once within any plant family, we are confident in this assumption. Based on A. dealbata canopies in the surveyed populations, which varied considerably with respect to health and the proportion of live canopy that flowered (Broadhurst and Young, 2006), each plant was assumed to produce a maximum of 10000 ovules. Though this is likely to represent an underestimate of ovule production, it is probably within an order of magnitude of the number of ovules in flowers that actually get visited by pollinators. The fraction of safe sites was assumed to be 0.75 based on field observations of occupancy and proportion of apparently suitable habitat. Populations were initiated with a lognormal age distribution with mean age of one, representing cohort recruitment following disturbance. The age of first reproduction was set at 3 years as flowering in A. auriculiformis begins at $\sim 18$ months with large quantities of seed produced by 4-5 years (Pinyopusarerk, 1990). The probability of mortality was set at 0.05 representing an approximate longevity of between 20 and 50 years. The pollen radius was set at $15 \mathrm{~m}$ which approximated field observations. While long distance dispersal of Acacia seed can occur (Whitney, 2002), evidence suggests that the dispersal distance is probably commonly only 1-2 $\mathrm{m}$ (Hughes and Westoby, 1992) so the seed radius was set at $1 \mathrm{~m}$. We assumed a relatively low rate of seedling establishment (0.01) since germination of Acacia seed is often stochastically driven by environmental perturbation and while mass germination events do occur, seedling survival is often poor, particularly if weed and grazing impacts are high (Auld, 1995; Clarke, 2002; Yates and Broadhurst, 2002). Using the parameters described, population dynamics were simulated using 100 replicate runs of 500 generations for each set of conditions which varied systematically for population size, which ranged from 10-500 plants representing the realistic observed range of $A$. dealbata densities per ha, and $S$ allele numbers of $3,5,10,20,30,50$ and 100.

\section{Results}

\subsection{Genetic diversity}

Insufficient seed was available in 2002 to estimate genetic diversity for Jerrabomberra and Campbell Park. Levels of genetic diversity varied among the remaining 12 populations (Table 2). Allelic richness (A) ranged from 1.4 at Adaminaby Cemetery, Gydzderick and Black Flat to 2.0 at Grabben Gullen and Queensgallery, while the mean number of alleles per 
Table 2 - Genetic diversity measures for Acacia dealbata populations

\begin{tabular}{|c|c|c|c|c|c|c|c|c|}
\hline Population & $\mathrm{N}$ & A & $A_{p}$ & $P$ & $H_{e}(s d)$ & $H_{\circ}(s d)$ & $F_{\text {IS }}$ & $p(1)$ \\
\hline Adaminaby cemetery & 15.0 & 1.4 & 2.3 & 28.6 & $0.10(0.20)$ & $0.09(0.17)$ & 0.098 & \\
\hline Jerrabomberra & - & - & - & - & - & - & - & \\
\hline Campbell park & - & - & - & - & - & - & - & \\
\hline Native dog & 10.8 & 1.6 & 2.3 & 50.0 & $0.12(0.17)$ & $0.13(0.18)$ & -0.064 & 1 \\
\hline Braidwood & 12.9 & 1.6 & 2.4 & 50.0 & $0.12(0.19)$ & $0.09(0.13)$ & 0.241 & \\
\hline Berrabangalo & 30.6 & 1.7 & 2.4 & 50.0 & $0.13(0.19)$ & $0.11(0.15)$ & 0.162 & 2 \\
\hline Adaminaby road & 32.7 & 1.5 & 2.2 & 42.9 & $0.13(0.19)$ & $0.13(0.18)$ & 0.002 & \\
\hline Gydzderick & 14.7 & 1.4 & 2.5 & 28.6 & $0.05(0.10)$ & $0.03(0.06)$ & 0.378 & \\
\hline Lade vale & 28.0 & 1.7 & 2.6 & 42.9 & $0.14(0.22)$ & $0.12(0.19)$ & 0.147 & \\
\hline Black flat & 9.00 & 1.4 & 2.0 & 42.9 & $0.07(0.08)$ & $0.06(0.08)$ & 0.200 & 1 \\
\hline Scabbing flat & 18.6 & 1.6 & 2.4 & 42.9 & $0.15(0.23)$ & $0.13(0.19)$ & 0.124 & \\
\hline Grabben Gullen & 38.7 & 2.0 & 3.0 & 57.1 & $0.10(0.15)$ & $0.10(0.14)$ & 0.044 & 4 \\
\hline Pudmans & 56.9 & 1.9 & 2.6 & 71.4 & $0.13(0.17)$ & $0.10(0.14)$ & 0.192 & 1 \\
\hline Queensgallery & 49.9 & 2.0 & 2.8 & 57.1 & $0.11(0.18)$ & $0.10(0.16)$ & 0.086 & 2 \\
\hline Mean & & 1.65 & 2.46 & 47.0 & 0.11 & 0.10 & & \\
\hline
\end{tabular}

polymorphic locus $\left(A_{\mathrm{p}}\right)$ ranged from 2.0 at Black Flat to 3.0 at Grabben Gullen. Low levels of polymorphic loci $(P)$ were also evident at Adaminaby Cemetery and Gydzderick (28.6\%) with high levels at Pudmans (71.4\%). Gene diversity $\left(H_{\mathrm{e}}\right)$ and heterozygosity $\left(H_{\circ}\right)$ were also lowest at Gydzderick (0.05 and 0.03, respectively) with $H_{e}$ being highest at Scabbing Flat (0.15) and $H_{\circ}$ being high at Adaminaby Road, Native Dog and Scabbing Flat. Elevated levels of inbreeding $\left(F_{\text {IS }}\right)$ were apparent at Gydzderick (0.378), Braidwood (0.241), Black Flat (0.200) and to a lesser extent at Pudmans (0.192), Berrabangalo (0.162) and Lade Vale (0.147) in contrast with other sites such as Adaminaby Road and Queensgallery, where inbreeding values approached zero. A single private allele was present at Native Dog, Black Flat and Pudmans while two alleles were restricted to Berrabangalo and Queensgallery and four unique alleles were found at Grabben Gullen.

\subsection{Mating system and genotype diversity}

High levels of outcrossing $\left(t_{m}\right)$ were evident across all populations (range 0.89-1.00, Table 3) with little evidence of biparental inbreeding $\left(t_{\mathrm{m}}-t_{\mathrm{s}}, 0-0.085\right)$. Correlated paternity $\left(r_{\mathrm{p}}\right)$ ranged from 0.034 at Adaminaby Road to 0.134 at Pudmans. A total of 213 genotypes were identified in progeny from the six populations. Fewer genotypes $(G)$ were observed in the three smaller populations of Adaminaby Road, Berrabangalo and Lade Vale (32-45) compared with the three larger populations (50-64, Table 3), however the proportion of unique genotypes was greater in smaller populations (23-34\%) relative to the larger populations (17-20\%). In the smaller populations there was, on average, one genotype for every two progeny $(G / n$, range $0.46-0.55)$ while in the larger populations there was one genotype for every three progeny (range 0.32-0.37). Genotype diversity values adjusted to five trees per population indicate that the $G / n$ differences observed were influenced by sampling effects. In contrast, differences between small and large populations for G-unique did not alter dramatically, and adjusting the sample size at Grabben Gullen and Pudmans resulted in fewer unique genotypes being detected.

\subsection{Growth trial}

The mean final percentage germination for 2002 seed ranged from $84 \%$ at Adaminaby Road to $100 \%$ at Gydzderick, while 2003 seed varied from $64 \%$ at Queensgallery to $100 \%$ at Adaminaby Cemetery and Berrabangalo (Fig. 2a). Most of the seed had germinated by week six with the average number of days to germination for 2002 seed ranging from 29 to 37 days (Berrabangalo-Adaminaby Road) whereas 2003 seed ranged from 26 to 42 days (Queensgallery-Adaminaby Cemetery).

Table 3 - Mating system and genotype diversity estimates for Acacia dealbata populations

\begin{tabular}{|c|c|c|c|c|c|c|c|c|}
\hline Population & $t_{\mathrm{m}}$ & $t_{m}-t_{s}$ & $r_{\mathrm{p}}$ & G & $G / n$ & Adjusted G/n & G-Unique (\%) & Adjusted G-unique (\%) \\
\hline Adaminaby road & 1.00 & 0.027 & 0.034 & 32 & 0.46 & 0.46 & 23 & 23 \\
\hline Berrabangalo & 0.99 & 0.085 & 0.067 & 42 & 0.55 & 0.55 & 27 & 27 \\
\hline Lade vale & 0.99 & 0.032 & 0.041 & 45 & 0.51 & 0.54 & 34 & 29 \\
\hline Grabben gullen & 0.98 & 0.049 & 0.075 & 50 & 0.32 & 0.35 & 19 & 15 \\
\hline Pudmans & 0.97 & 0.010 & 0.134 & 64 & 0.32 & 0.46 & 17 & 16 \\
\hline Queensgallery & 0.89 & 0.000 & 0.096 & 59 & 0.37 & 0.48 & 20 & 22 \\
\hline
\end{tabular}

$t_{m}$, outcrossing rate; $t_{m}-t_{s}$, biparental inbreeding; $r_{p}$, correlated paternity; $G$, number of genotypes; $G / n$, genotype diversity; Adjusted $G / n$, mean genotype diversity adjusted for sample size; G-unique, proportion of progeny with genotypes unique to population; Adjusted G-unique, mean proportion of progeny with genotypes unique to population adjusted for sample size. 

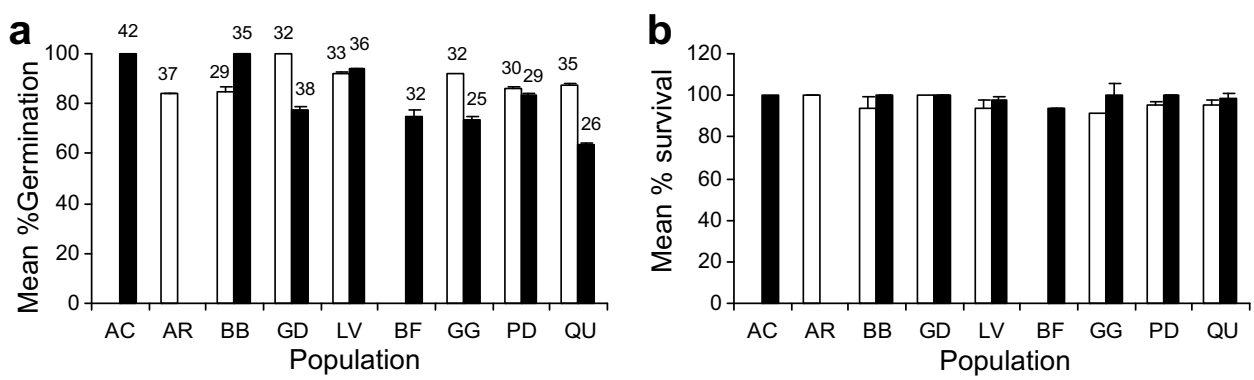

Fig. 2 - Mean final germination percentage (a) and mean final survival percentage (b) for Acacia dealbata growth trial. Open bars are 2002, closed bars are 2003. Populations arranged in order of increasing population size. Numbers above bars indicate mean days to germination.

Despite the variability in germination percentage and days to germination, seedling survivorship was uniformly high in all populations (>90\%), irrespective of the year (Fig. 2b). Generalized linear mixed models indicated that germination percentage differed significantly between years $\left(\mathrm{df}_{1,164} p=0.012\right)$ and among populations $\left(\mathrm{df}_{7,164} p=0.006\right)$.

Significant differences also existed between years and among populations for the progeny growth responses. Growth measured at week 16 (Height 1) differed significantly between years and among populations (Table 4), however, these differences did not persist to the second measuring point at 24 weeks (Height 2). Predictive means generated from restricted maximum likelihood analysis indicated that 2002 progeny were taller than 2003 progeny at Gydzderick and Grabben Gullen while the reverse occurred at Lade Vale, Pudmans and Queensgallery (Fig. 3a). The number of phyllodes produced did not differ at the first measurement (Phyllode 1), but a highly significant population effect was evident by the second measurement (Phyllode 2, Table 4). More phyllodes were produced by 2002 progeny from Gydzderick, Lade Vale and Grabben Gullen while more were produced by 2003 progeny from Berrabangalo, Pudmans and Queensgallery (Fig. 3b). Shoot weight did not vary between years or among populations, however, a significant population effect as well as the interaction term between population and year were evident for root weights (Table 4) with the same population-based trends as observed in Phyllode 2 being evident (Fig. 3c). A highly significant population effect also existed for the shoot to root ratio (Shoot:root) (Fig. 3d) and this difference was maintained following removal of the high Black Flat value (Wald $=22.19 \mathrm{df}_{7} p=0.002$ ). Heavier 2002 seed was associated with higher survival $\left(F_{1,5}=8.62, p=0.032, R^{2}=61.4 \%\right)$ while heavier 2003 seed was associated with a higher shoot to root ratio $\left(F_{1,4}=6.48, p=0.044, R^{2}=51.9 \%\right)$. Although there were several significant associations between the genetic diversity measures and the growth responses, these were due entirely to the influence of Gydzderick which was represented by the progeny of a single tree. Removing this population from the analysis removed all significant associations. Higher outcrossing rates were, however, consistently associated with a lower shoot to root ratio $\left(F_{1,4}=23.97, p=0.008, R^{2}=85.7 \%\right)$.

\subsection{Landscape influences on genetic diversity, mating systems, and growth}

Several of the landscape variables significantly influenced genetic, mating system and growth estimates with population size and plant density being major drivers (Fig. 4). Larger populations were associated with higher genetic diversity including allelic richness $\left(A ; F_{1,10}=13.57, p=0.004, R^{2}=57.6 \%\right)$, the mean number of alleles per polymorphic locus $\left(A_{p}\right.$; $\left.F_{1,10}=5.43, p=0.042, R^{2}=35.2 \%\right)$ and the percentage of polymorphic loci $\left(P ; F_{1,10}=6.84, p=0.026, R^{2}=40.6 \%\right.$. Outcrossing rates were significantly lower in larger populations $\left(F_{1,4}=15.05, p=0.018, R^{2}=79 \%\right)$ although caution should be exercised interpreting this result given the small sample size, and these populations had poorer 2003 germination $\left(F_{1,6}=9.55, p=0.021, R^{2}=61.4 \%\right)$ and took longer to germinate $\left(F_{1,6}=24.79, p=0.003, R^{2}=80.5 \%\right)$. Progeny from larger populations also had poorer 2002 survival $\left(F_{1,5}=9.96, p=0.025\right.$, $\left.R^{2}=66.5 \%\right)$ and a higher 2002 shoot to root ratio $\left(F_{1,5}=15.22\right.$, $p=0.010, R^{2}=76.1 \%$ and $F_{1,5}=15.90, p=0.011, R^{2}=75.3 \%$,

\section{Table 4 - Restricted maximum likelihood analyses of the seven growth responses for the Acacia dealbata growth trial}

\begin{tabular}{|c|c|c|c|c|c|c|}
\hline \multirow[t]{2}{*}{ Growth response } & \multicolumn{2}{|c|}{ Year } & \multicolumn{2}{|c|}{ Population } & \multicolumn{2}{|c|}{ Interaction } \\
\hline & Wald $_{(\mathrm{df}=1)}$ & $p$ & Wald $_{(\mathrm{df}=8)}$ & $p$ & Wald $_{(\mathrm{df}=5)}$ & $p$ \\
\hline Height 1 (16 weeks) & 6.53 & 0.011 & 59.93 & $<0.001$ & ns & ns \\
\hline Height 2 (24 weeks) & ns & ns & ns & ns & ns & ns \\
\hline Phyllode 1 (16 weeks) & ns & ns & ns & ns & ns & ns \\
\hline Phyllode 2 (24 weeks) & ns & ns & 49.27 & $<0.001$ & ns & ns \\
\hline Shoot & ns & ns & ns & ns & $\mathrm{ns}$ & ns \\
\hline Root & ns & ns & 16.20 & 0.004 & 15.01 & 0.010 \\
\hline Shoot:root & ns & ns & 49.55 & $<0.001$ & ns & ns \\
\hline
\end{tabular}



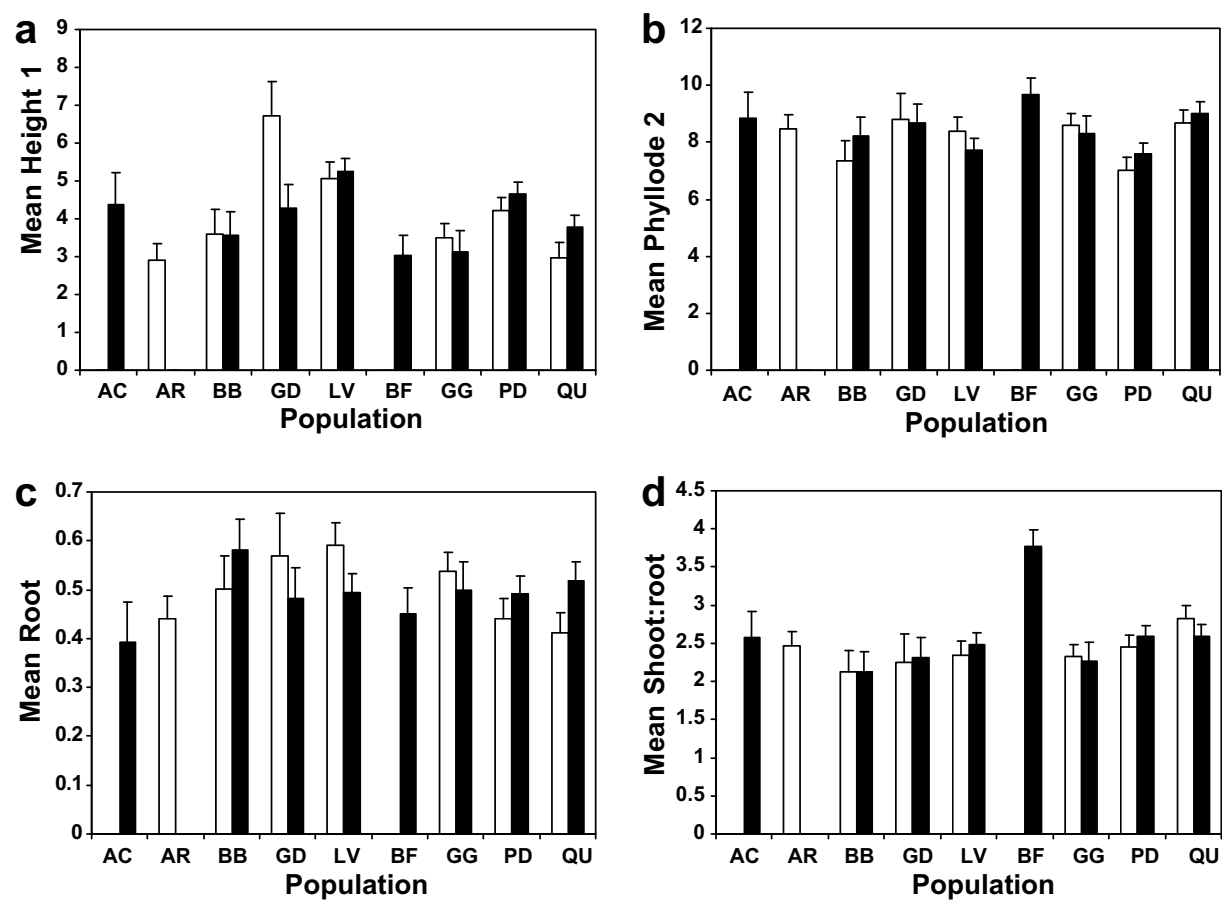

Fig. 3 - Restricted maximum likelihood generated means for Acacia dealbata populations for (a) mean height week 16; (b) mean phyllode week 24; (c) mean root weight; and, (d) mean shoot to root ratio. Populations arranged in order of increasing size. Open bars are 2002, closed bars are 2003. Lines above bars indicate standard errors.

respectively). Population density was also important, with more dense populations having significantly higher $A_{p}$ $\left(F_{1,10}=4.99, p=0.049, R^{2}=33.3 \%\right)$ while their progeny had slow 2002 germination $\left(F_{1,5}=7.40, p=0.042, R^{2}=59.7 \%\right)$ and poorer 2002 survival $\left(F_{1,5}=7.02, p=0.045, R^{2}=58.4 \%\right)$. These progeny also had a higher 2002 shoot to root ratio $\left(F_{1,5}=15.90\right.$, $\left.p=0.011, R^{2}=75.3 \%\right)$ and increased 2002 phyllode production $\left(F_{1,5}=8.89, p=0.030, R^{2}=64.2 \%\right)$. Increasingly isolated populations had significantly lower $A_{p} \quad\left(F_{1,10}=11.91, p=0.005\right.$, $\left.R^{2}=56.5 \%\right)$ while those with fewer exotic species exhibited more polymorphic loci $\left(F_{1,10}=8.60, p=0.015, R^{2}=46.2 \%\right)$.

\subsection{Simulated effects of a gametophytic self-} incompatibility system on population viability

Results of three output parameters from the simulation models are presented: (i) mate availability: which is the mean number of genetically compatibility mates within pollination range; (ii) proportion seed set: the mean proportion of ovules that are converted to seed; and, (iii) persistence: the mean number of generations for which a population persists. Fig. 5 shows the relationship of these three variables against population size and $S$ allele number modelled as a spline 3D surface using AXUM 7 (MathSoft, 2001). The relationships indicate that for at least some of the modelled parameter space there are effects of both population size and $S$ allele number for all three demographic response variables. But the areas of dominant effects and the space in which there are clear interactions and trade-offs varies among variables, with generally smaller ranges of affect for both parameters as the response variable measured moves along the demographic pathway from potential mate availability to actual population persistence. Fig. 5 (top) shows linear positive effects of both $S$ allele number and population size on mean mate availability below 100 individuals and $40 \mathrm{~S}$ alleles. Indeed below $40 \mathrm{~S}$ alleles, genetic diversity is always the primary determinant of mate availability, regardless of population size, imposing severe restrictions on mate availability below $20 \mathrm{~S}$ alleles even in the largest populations observed. Beyond 40 incompatibility alleles, mate availability increases steadily with population size to a maximum of close to 0.5 in populations bigger than 400 reproductive individuals. Forty $S$ alleles also represents a threshold of maximum effect for proportion seed set (Fig. 5 middle) with strong effects of genetic diversity on seed production for populations bigger than 100 individuals. Below 100 individuals, S allele richness interacts with population size to determine seed set, while above $40 \mathrm{~S}$ alleles, population size itself is the primary driver of the likelihood that an ovule is successfully fertilised, but this effect only occurs up to a population size of about 100 individuals. Population persistence was the least responsive variable with interacting effects of $\mathrm{S}$ allele number and population size observed only up to 200 individuals and $40 \mathrm{~S}$ alleles (Fig. 5 bottom). Unlike mate availability and seed set, the effect of low $S$ allele numbers $(<40)$ was dramatically reduced with increasing population size so that $S$ alleles had very little effect on long-term population persistence when starting populations were bigger then 200.

\section{Discussion}

Studies of fragmented common and widespread plant species are revealing that changes in vegetation abundance and 


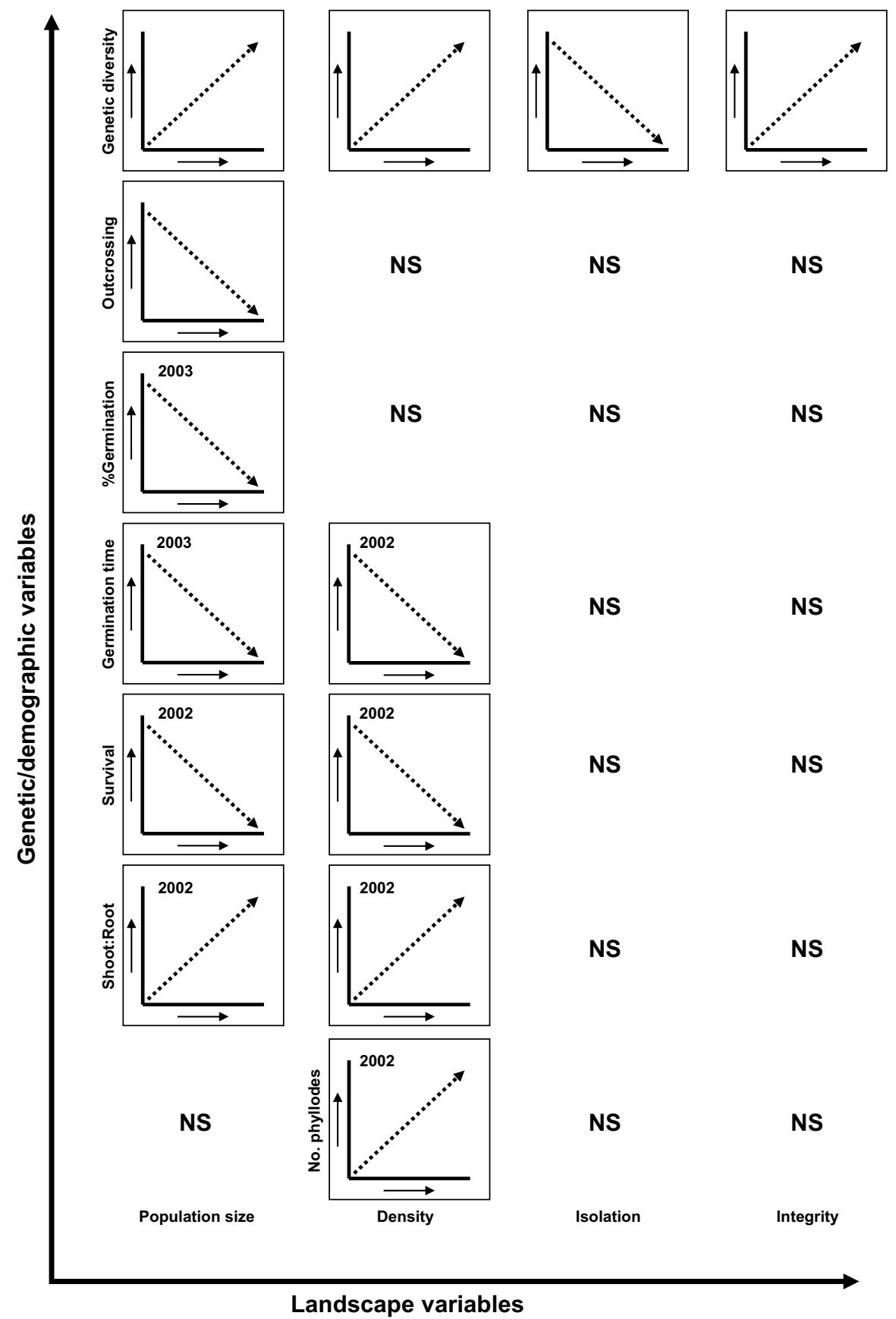

Fig. 4 - Representations of major landscape variables and genetic and growth responses for Acacia dealbata. Slopes are indicative only. Arrows indicate increasing magnitude of the landscape variable or response.

configuration are impacting on these species in a manner similar to that experienced by rare species (Honnay and Jacquemyn, 2007; Prober and Brown, 1994; Tomimatsu and Ohara, 2002, 2003; Vergeer et al., 2003). The results of this study add more evidence of such responses, with $A$. dealbata exhibiting genetic responses to reduced population size, and an interaction between genetic and demographic effects mediated by its self-incompatibility system that is likely to reduce the viability of small ( $<200$ individuals) genetically depauperate $(<40 \mathrm{~S}$ alleles) populations. These results refute a misconception that landscape presence equates with persistence. As pointed out by Jacquemyn et al. (2003), while plants may continue to subsist, they do not necessarily contribute to long-term viability through reproductive success. Here, despite prolific flowering displays, A. dealbata is constrained by its breeding system and these limitations probably affect the majority of fragmented Acacia populations in agricultural landscapes across the southern tablelands of New South Wales.

\subsection{Genetic diversity}

Despite seemingly similar levels of genetic diversity across A. dealbata populations, some significant associations were 


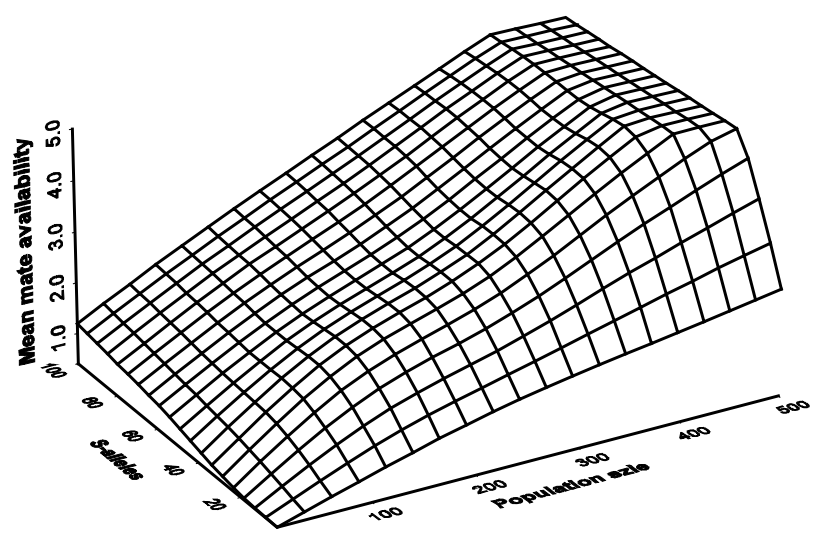

populations can also be relatively weed free due to their high conservation value being actively maintained by local land management agencies. The importance of habitat quality for maintaining demographic and ecological function within plant populations is not well understood, but examples outlining the influence of habitat quality on pollinator abundance and reproductive success (Brys et al., 2003; Moody-Weis and Heywood, 2001; Schmidt and Jensen, 2000) as well as soil quality on reproductive success and mortality (Brys et al., 2005) do exist. As such, the importance of habitat quality may represent an important, and as yet underestimated, influence on population persistence.

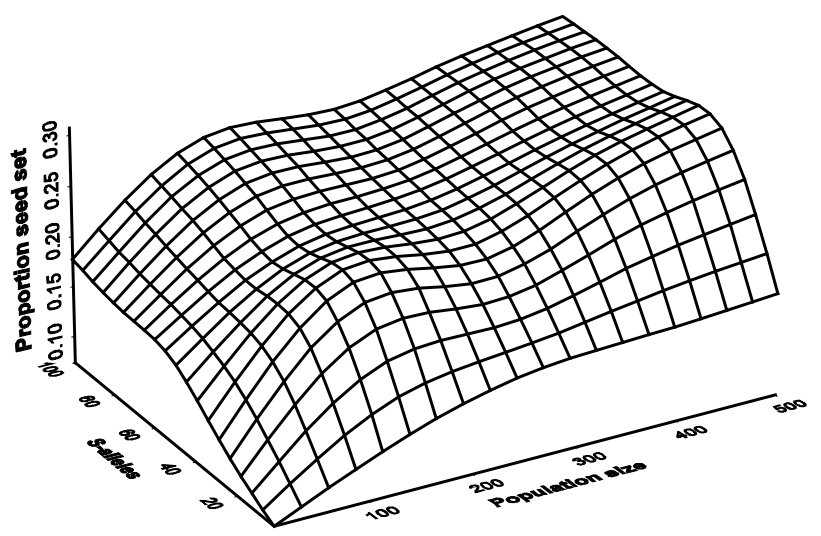

\subsection{Mating system and genotype diversity}

Uniformly high outcrossing rates and low biparental inbreeding in A. dealbata are comparable with results obtained from marker-based assessments of the breeding system of other acacias (Casiva et al., 2004; Moran et al., 1989), and provide strong evidence that reproduction is being mediated by a self-incompatibility mechanism. Given this reproductive strategy, it is not surprising that few differences in the mating system estimates were observed among A. dealbata populations. In contrast, the genotype composition of seed crops exhibited important differences between the small and large populations sampled with genotype diversity $(G / n)$ and the proportion of unique genotypes (G-unique) being higher in the three smaller populations. Sampling effects appear to explain these differences for genotype diversity, however, adjusting for sample size did not explain the higher G-unique in seed crops from smaller populations. Theoretically, small, self-incompatible populations should have fewer parental genotypes resulting in disassortative mating generating fewer genotypes. One possible explanation for the increased production of G-unique is that these small A. dealbata populations are not static landscape elements, and the higher G-unique reflects pollinator interactions across broader spatial scales. In fact limited mate availability in small populations could actually drive such an effect as, owing to the negative frequency selection acting at the incompatibility locus, the relative fitness of immigrant pollen grains is increased as they are more likely to contain locally novel $S$ alleles.

Indeed, Adaminaby Road, Berrabangalo and Lade Vale ex-

Fig. 5 - Results of self-incompatibility modelling for Acacia dealbata at various population sizes and number of $S$ alleles. Top - mate availability, middle - proportion seed set, bottom - population persistence.

evident between several of these diversity estimates and some of the landscape variables. For example, population size and isolation were important predictors for allelic richness, the mean number of alleles per polymorphic locus, and the percentage of polymorphic loci. Similar influences on genetic diversity have been observed in both rare and common species (Buza et al., 2000; Hensen and Oberprieler, 2005; Vergeer et al., 2003; Young et al., 2000). Perhaps one of the most interesting findings, however, was the strong positive association between remnant integrity and polymorphic loci. While it could be argued that this simply reflects larger populations being more resilient to weed invasion, smaller A. dealbata ist in highly modified agricultural pastures surrounded by discrete thickets of trees that are spatially distributed to preclude these being incompatible suckers. While direct evidence that these thickets represent compatible genotypes was not gathered, poor reproductive output would indicate that few compatible genotypes exist within these sites as well as in the surrounding landscape. In contrast, if compatible genotypes exist, reproductive output should be less compromised, generating more unique genotypes. Unfortunately reproductive data are not available for Adaminaby Road, while at Berrabangalo fertilisation success and pod set were consistently high but seed production was poor and it is unclear whether this reflects extremely poor environmental conditions or the elimination of inbred progeny. In contrast, reproductive output at Lade Vale was consistently comparable with that of large populations (Broadhurst and Young, 2006) suggesting that 'genetic rescue' of this small population 
may be occurring from the surrounding landscape. Several studies now indicate that gene flow is occurring across much broader geographic distances in fragmented landscapes than previously recognised, and that isolated trees do contribute to the pollen pool of nearby populations (Dick et al., 2003; White et al., 2002; Young et al., 2005).

\subsection{Growth}

Although self-incompatibility does exist in acacias, it is imperfect and increased levels of selfing and elevated inbreeding have been observed (Butcher et al., 1998; Coates et al., 2006). Progeny produced via this reproductive pathway are often less fit than their outbred counterparts (Harwood et al., 2004; Moffett and Nixon, 1974). There was little evidence of elevated inbreeding influencing progeny fitness in this study which probably reflects the difficulties involved in capturing inbred seed since self-incompatibility systems have evolved to eliminate the negative effects associated with inbreeding early in the reproductive cycle. Further, the few significant associations between progeny growth and landscape variables were often unexpected and difficult to explain (summarised in Fig. 4). For example, 2002 progeny from larger and more dense populations had poorer survival while 2003 progeny from larger populations had poorer germination and took longer to germinate. Given that most of the evidence for poor progeny fitness associated with inbreeding comes from short-lived plants that have experienced several generations since fragmentation (Kolb, 2005; Luijten et al., 2000), it is perhaps not unexpected that we observed few negative effects associated with long-lived A. dealbata populations which have only been through 1-2 generations post-fragmentation.

\subsection{Modelling population persistence}

The demographic data used to parameterise the simulation model were a mixture of values based on field observations of A. dealbata from this and a previous study (Broadhurst and Young, 2006), published literature values, and the critical assumption that that the self-incompatibility system in this species is gametophytic. However, the results of the analysis of the effect of $S$ allele richness and reproductive population are very interesting.

The key results are that there are clear negative effects of both reduced population size (demographic variable) and S allele richness (genetic variable) on population dynamics and that these two factors interact at small population sizes (<200 reproductive plants) and $S$ allele numbers $(<40)$. Interestingly, effects are more pronounced but less important early in the reproductive cycle in that they affect mate availability more than seed production which, in turn, is more responsive to both parameters than ultimate population persistence. Despite this reducing leverage on persistence through the life cycle, it is clear that in populations of fewer than 200 plants and with less than $20 \mathrm{~S}$ alleles, genetic constraints on demographic performance due to the self-incompatibility system are probably real and significantly constrain population viability. These findings are consistent with the reduced reproductive output previously observed in small A. dealbata populations (Broadhurst and Young, 2006) and mean that it is likely such effects could represent an important constraint to persistence for the many small populations that characterise the study landscape.

This situation represents an interesting ecological and evolutionary paradox in that the Acacia self-incompatibility system, which presumably evolved as a mechanism to negate geitonogamy associated with the dense floral architecture of acacia inflorescences (Kenrick et al., 1986; Kenrick and Knox, 1989a; Moncur et al., 1991), is now operating as a demographic constraint due to loss of genetic variation at the $S$ locus in these small fragmented populations. This means that the very mechanism designed by evolution to prevent one genetic problem that has fitness implications - inbreeding, has generated another genetically-based reproductive constraint mate limitation. Such $S$ allele limitation of seed production has been observed previously in small populations of selfincompatible species (DeMauro, 1993; Pickup and Young, 2008; Willi et al., 2005; Young et al., 2000) but the long-term demographic consequences have only recently begun to be quantitatively explored (Hoebee et al., 2008).

\subsection{Conservation implications}

The trajectory and intensity of genetic and/or demographic signals generated by population fragmentation is highly dependent on a species' biology with plant responses often varying considerably (Eriksson and Ehrlen, 2001). It is also apparent from this study that integrating demographic and genetic analyses is important since the most significant driver of responses to fragmentation in A. dealbata was a genetically-controlled reproductive strategy, but the signal generated was only observable in a demographic context, namely reproductive output and modelled population persistence. Few significant associations between genetic, mating system and growth responses and the landscape variables of fragmented A. dealbata populations were observed in this study suggesting that these are not likely to be major constraints to persistence. The companion study, however, clearly indicated that reproductive failure is a significant constraint to the persistence of many smaller populations (Broadhurst and Young, 2006), and the future of these populations will be compromised if seed production falls below natural levels of replacement. Fortuitously, persistence in small A. dealbata populations is likely to be buffered to some extent by a soil seed bank that germinates rapidly following disturbance (Auld, 1986; Brown et al., 2003), but as reproductive output declines over time, these reserves will eventually be depleted.

Remnant vegetation represents a significant portion of many fragmented landscapes that does not require large and expensive intervention to restore biodiversity and ensure continued ecological functioning. Identifying constraints to the longevity of these remnants is critical for species management and conservation in these landscapes where trade-offs between maintaining agricultural productivity and biodiversity often exist. Accordingly, the modelling data indicate that the introduction of new germplasm into small populations is likely to dramatically improve mate availability, reproductive output and population persistence. As a highly fecund species that is relatively easy to collect, such a strategy is likely to be 
both time and cost-effective. Of further consideration is that these smaller populations probably require management at broader landscape levels, rather than as single entities although this would require a detailed understanding of the scale and importance of gene flow for this species.

A. dealbata was chosen for this study to represent a large functional element in the Australian flora. A disturbing implication from the negative responses observed, is that many other Acacia species are likely to also be similarly impacted by fragmentation. The decline or loss of these abundant and important components of vegetation communities across southern Australia will dramatically alter levels of natural vegetation cover and severely impact on numerous mutualistic associations. Perhaps this now requires an investment shift of limited conservation funds from an individuallybased rare species management approach towards a more integrated, landscape-focussed strategy where the maintenance of remnant vegetation functionality is likely to benefit both rare and common species.

While more studies are required to determine general trajectories of these responses in a broader range of common species, the loss of the most abundant components of vegetation communities is of considerable concern. Demographic and genetic challenges to remnant plant communities following fragmentation threaten not only the plant species present, but also the many faunal and microbial species that these communities support. This is particularly critical in the agricultural regions where biodiversity levels in many regions are already critically low following broadscale land clearing and intensive agricultural modification.

\section{Acknowledgements}

This research was conducted as part of Land and Water Australia Grant (CPI 10). Thanks to Liz Gregory for technical assistance during the course of this research and to Pete Thrall for SI model development.

\section{R E F E R E N C E S}

ACT Government, 2004. Woodlands for Wildlife: ACT Lowland Conservation Strategy. Action Plan No. 27. Environment ACT, Canberra.

Adams, M.A., Attiwill, P.M., 1984. Role of Acacia spp. in nutrient balance and cycling in regenerating Eucalyptus regnans F. Muell. forests. II Field studies of acetylene reduction. Australian Journal of Botany 32, 217-223.

Agren, J., 1996. Population size, pollinator limitation, and seed set in the self-incompatible herb Lythrum salicaria. Ecology 77, 1779-1790.

Aguilar, R., Galetto, L., 2004. Effects of forest fragmentation on male and female reproductive success in Cestrum parqui (Solanaceae). Oecologia 138, 513-520.

Aizen, M.A., Feinsinger, P., 1994. Forest fragmentation, pollination, and plant reproduction in a Chaco dry forest, Argentina. Ecology 75, 330-351.

Aldrich, P.R., Hamrick, J.L., Chavarriaga, P., Kochert, G., 1998. Microsatellite analysis of demographic genetic structure in fragmented populations of the tropical tree Symphonia globulifera. Molecular Ecology 7, 933-944.
Auld, T.D., 1986. Population dynamics of the shrub Acacia suaveolens (Sm) Willd.: fire and the transition to seedlings. Australian Journal of Ecology 11, 373-385.

Auld, T.D., 1995. Seedling survival under grazing in the arid perennial Acacia oswaldii. Biological Conservation 72, 27-32.

Australian State of the Environment Committee, 2001. Australia State of the Environment 2001, Independent Report to the Commonwealth Minister for the Environment and Heritage. CSIRO Publishing on behalf of the Department of the Environment and Heritage, Canberra.

Bacles, C.F.E., Lowe, A.J., Ennos, R.A., 2004. Genetic effects of chronic habitat fragmentation on tree species: the case of Sorbus aucuparia in a deforested Scottish landscape. Molecular Ecology 13, 573-584.

Bernhardt, P., 1989. The floral biology of Australian Acacia. In: Stirton, C.H., Zarucchi, J.L. (Eds.), Advances in Legume Biology. Missouri Botanic Gardens, St Louis Missouri, pp. 263-281.

Broadhurst, L.M., Young, A.G., 2006. Reproductive constraints to the long-term persistence of fragmented Acacia dealbata (Mimosaceae) populations in southeast Australia. Biological Conservation 133, 512-526.

Broadhurst, L.M., Young, A.G., 2007. Seeing the wood and the trees - predicting the future for fragmented plant populations in Australian landscapes. Australian Journal of Botany 55, 250260.

Brown, A.H.D., Allard, R.W., 1970. Estimation of the mating system in open-pollinated maize populations using isozyme polymorphisms. Genetics 66, 133-145.

Brown, J., Enright, N.J., Miller, B.P., 2003. Seed production and germination in two rare and three common co-occurring Acacia species from south east Australia. Austral Ecology, 28.

Brys, R., Jacquemyn, H., Endels, P., de Blust, G., Hermy, M., 2005. Effect of habitat deterioration on population dynamics and extinction risks in a previously common perennial. Conservation Biology 19, 1633-1643.

Brys, R., Jacquemyn, H., Endels, P., Hermy, M., De Blust, G., 2003. The relationship between reproductive success and demographic structure in remnant populations of Primula veris. Acta Oecologica 24, 247-253.

Butcher, P.A., Moran, G.F., Perkins, H.D., 1998. RFLP diversity in the nuclear genome of Acacia mangium. Heredity 81, 205-213.

Buza, L., Young, A., Thrall, P., 2000. Genetic erosion, inbreeding and reduced fitness in fragmented populations of the endangered tetraploid pea Swainsona recta. Biological Conservation 93, 177-186.

Byrne, M., Elliott, C.P., Yates, C.J., Coates, D.J., 2008. Maintenance of high pollen dispersal in Eucalyptus wandoo, a dominant tree of the fragmented agricultural region in Western Australia. Conservation Genetics 9, 97-105.

Casiva, P.V., Vilardi, J.C., Cialdella, A.M., Saidman, B.O., 2004. Mating system and population structure of Acacia aroma and A. macracantha (Fabaceae). American Journal of Botany 91, 5864.

Clarke, P.J., 2002. Experiments on tree and shrub establishment in temperate grassy woodlands: seedling survival. Austral Ecology 27, 606-615.

Coates, D.J., Tischler, G., McComb, J.A., 2006. Genetic variation and the mating system in the rare Acacia sciophanes compared with its common sister species Acacia anfractuosa (Mimosaceae). Conservation Genetics 7, 931-944.

Cunningham, S.A., 2000. Effects of habitat fragmentation on the reproductive ecology of four plant species in mallee woodland. Conservation Biology 14, 758-768.

de Nettancourt, D., 1997. Incompatibility in angiosperms. Sexual Plant Reproduction 10, 185-199.

DeMauro, M.M., 1993. Relationship of breeding system to rarity in the Lakeside Daisy (Hymenoxys acaulis var. glabra).

Conservation Biology 7, 542-550. 
Dick, C.W., Etchelecu, G., Austerlitz, F., 2003. Pollen dispersal of tropical trees (Dinizia excelsa: Fabaceae) by native insects and African honeybees in pristine and fragmented rainforest. Molecular Ecology 12, 753-764.

Donaldson, J., Nanni, I., Zachariades, C., Kemper, J., 2002. Effects of habitat fragmentation on pollinator diversity and plant reproductive success in renosterveld shrublands of South Africa. Conservation Biology 16, 1267-1276.

Eriksson, O., Ehrlen, J., 2001. Landscape fragmentation and the viability of plant populations. In: Silvertown, J., Antonovics, J. (Eds.), Integrating Ecology and Evolution in a Spatial Context. Blackwell Science, Oxford, pp. 157-175.

Garcia, D., Chacoff, N.P., 2007. Scale-dependent effects of habitat fragmentation on hawthorn pollination, frugivory, and seed predation. Conservation Biology 21, 400-411.

Groom, M.J., 2001. Consequences of subpopulation isolation for pollination, herbivory and population growth in Clarkia concinna (Onagraceae). Biological Conservation 100, 55-63.

Harwood, C.E., Thinh, H.H., Quang, T.H., Butcher, P.A., Williams, E.R., 2004. The effect of inbreeding on early growth of Acacia mangium in Vietnam. Silvae Genetica 53, 65-69.

Hensen, I., Oberprieler, C., 2005. Effects of population size on genetic diversity and seed production in the rare Dictamnus albus (Rutaceae) in central Germany. Conservation Genetics 6, 63-73.

Hoebee, S.E., Thrall, P.H., Young, A.G., 2008. Integrating population demography, genetics and self-incompatibility in a viability assessment of the Wee Jasper Grevillea (Grevillea iaspicula McGill, Proteaceae). Conservation Genetics 9, 515-529.

Honnay, O., Jacquemyn, H., 2007. Susceptibility of common and rare plant species to the genetic consequences of habitat fragmentation. Conservation Biology 21, 823-831.

Hooftman, D.A.P., Billeter, R.C., Schmid, B., Diemer, M., 2004. Genetic effects of habitat fragmentation on common species of Swiss fen meadows. Conservation Biology 18, 1043-1051.

Hopmans, P., Douglas, L.A., Chalk, P.M., 1983. Nitrogen fixation associated with Acacia dealbata Link seedlings as estimated by the acetylene reduction assay. Australian Journal of Botany 31, 331-339.

Hughes, L., Westoby, M., 1992. Fate of seeds adapted for dispersal by ants in Australian sclerophyll vegetation. Ecology 73, 12851299.

Jacquemyn, H., van Rossum, F., Brys, R., Endels, P., Hermy, M., Triest, L., De Blust, G., 2003. Effects of agricultural land use and fragmentation on genetics, demography and population persistence of the rare Primula vulgaris, and implications for conservation. Belgium Journal of Botany 136, 5-22.

Kenrick, J., Kaul, V., Williams, E.G., 1986. Self-incompatibility in Acacia retinoides: site of pollen-tube arrest is the nucellus. Planta 169, 245-250.

Kenrick, J., Knox, R.B., 1989a. Pollen-pistil interactions in Leguminosae (Mimosoideae). In: Stirton, C.H., Zarucchi, J.L. (Eds.), Advances in Legume Biology. St Louis Missouri, Missouri Botanic Gardens, pp. 127-156.

Kenrick, J., Knox, R.B., 1989b. Quantitative analysis of selfincompatibility in trees of seven species of Acacia. Journal of Heredity 80, 240-245.

Khanna, P.K., 1997. Comparison of growth and nutrition of young monocultures and mixed stands of Eucalyptus globulus and Acacia mearnsii. Forest Ecology and Management 94, 105-113.

Kolb, A., 2005. Reduced reproductive success and offspring survival in fragmented populations of the forest herb Phyteuma spicatum. Journal of Ecology 93, 1226-1237.

Krauss, S.L., Hermanutz, L., Hopper, S.D., Coates, D.J., 2007. Population-size effects on seeds and seedlings from fragmented eucalypt populations: implications for seed sourcing for ecological restoration. Australian Journal of Botany 55, 390-399.
Lewis, P., Zaykin, D., 2001. Genetic Data Analysis: Computer Program for the Analysis of Allelic Data. Version 1.0 (d16c). Free program distributed by the authors over the internet from $<$ http://lewis.eeb.uconn.edu/lewishome/software.html>.

Lienert, J., 2004. Habitat fragmentation effects on fitness of plant populations - a review. Journal for Nature Conservation 12, 5372.

Luijten, S.H., Dierick, A., Gerard, J., Oostermeijer, B., Raijmann, L.E., den Nijs, H.C.M., 2000. Population size, genetic variation, and reproductive success in a rapidly declining, selfincompatible perennial (Arnica montana) in The Netherlands. Conservation Biology 14, 1776-1787.

Maslin, B., 2001. In: Acacia dealbata, In Flora of Australia, Vol. 11A:234. ABRS/CSIRO Publishing, Melbourne.

MathSoft, 2001. Axum 7. Insightful Corporation, Seattle.

McGranahan, M., Bell, J.C., Moran, G.F., Slee, M., 1997. High genetic divergence between geographic regions in the highly outcrossing species Acacia aulacocarpa Cunn. ex Benth. Forest Genetics 4, 1-13.

McIntyre, S., Hobbs, R., 1999. A framework for conceptualizing human effects on landscapes and its relevance to management and research models. Conservation Biology 13, 1282-1292.

Moffett, A.A., Nixon, K.M., 1974. The effects of self-fertilization in green wattle (Acacia decurrens (J.Wendl.) Willd.) and black wattle (A. mearnsii de Wild.). Wattle Research Institute Report 1973-1974, Natal.

Moncur, M.W., Morris, R.J., Grant, J.E., 1991. Factors limiting seed production in Acacia mearnsii. In: Turnbull, J.W. (Ed.), Conferences in Tropical Acacia Research. ACIAR Research, Bangkok, pp. 20-25.

Moody-Weis, J.M., Heywood, J.S., 2001. Pollination limitation to reproductive success in the Missouri evening primrose. American Journal of Botany 88, 1615-1622.

Moran, G.F., Muona, O., Bell, J.C., 1989. Breeding systems and genetic diversity in Acacia auriculiformis and A. crassicarpa. Biotropica 21, 250-256.

Paschke, M., Abs, C., Schmid, B., 2002. Relationship between population size, allozyme variation, and plant performance in the narrow endemic Cochlearia bavarica. Conservation Genetics 3, 131-144.

Pickup, M., Young, A.G., 2008. Population size, self-incompatibility and genetic rescue in diploid and tetraploid races of Rutidosis leptorrhynchoides (Asteraceae). Heredity 100, 268-274.

Pinyopusarerk, K., 1990. Acacia auriculiformis: An Annotated Bibliography Winrock International and ACIAR, Canberra.

Prober, S.M., Brown, A.H.D., 1994. Conservation of grassy white woodlands: population genetics and fragmentation of Eucalyptus albens. Conservation Biology 8, 1003-1013.

Prober, S.M., Thiele, K.R., Lunt, I.D., 2002. Identifying ecological barriers to restoration in temperate grassy woodlands: soil changes associated with different degradation states. Australian Journal of Botany 50, 699-712.

Ritland, K., 1989. Correlated matings in the partial selfer, Mimulus guttatus. Evolution 43, 848-859.

Ritland, K., 1990. A series of FORTRAN computer programs for estimating plant mating systems. Journal of Heredity 81, 235237.

Ritland, K., 2002. Extensions of models for the estimation of mating systems using $n$ independent loci. Heredity 88, 221228.

Rodriguez-Cabal, M.A., Aizen, M.A., Novaro, A.J., 2007. Habitat fragmentation disrupts a plant-disperser mutualism in the temperate forest of South America. Biological Conservation 139, 195-202.

Schmidt, K., Jensen, K., 2000. Genetic structure and AFLP variation of remnant populations in the rare plant Pedicularis palustris (Scrophulariaceae) and its relation to population size and 
reproductive components. American Journal of Botany 87, 678-689.

Sharpe, D.J., Goldingay, R.L., 1998. Feeding behaviour of the squirrel glider at Bungawalbin Nature Reserve, north-eastern New South Wales. Wildlife Research 25, 243-254.

Smith, A.P., 1984. Diet of Leadbeaters possum, Gymnobelideus leadbeateri (marsupialia). Australian Wildlife Research 11, 265273.

Sork, V.L., Davis, F.W., Smouse, P.E., Apsit, V.J., Dyer, R.J., Fernandez, J.F., Kuhn, B., 2002. Pollen movement in declining populations of California valley oak, Quercus lobata: where have all the fathers gone? Molecular Ecology 11, 1657-1668.

Thums, M., Klaassen, M., Hume, I.D., 2005. Seasonal changes in the diet of the long-nosed bandicoot (Perameles nasuta) assessed by analysis of faecal scats and of stable isotopes in blood. Australian Journal of Zoology 53, 87-93.

Tomimatsu, H., Ohara, M., 2002. Effects of forest fragmentation on seed production of the understorey herb Trillium camschatcense. Conservation Biology 16, 1277-1285.

Tomimatsu, H., Ohara, M., 2003. Genetic diversity and local population structure of fragmented populations of Trillium camschatcense (Trilliaceae). Biological Conservation 109, 249-258.

van Rossum, F., Campos de Sousa, S., Triest, L., 2004. Genetic consequences of habitat fragmentation in an agricultural landscape on the common Primula veris, and comparison with its rare congener, P. vulgaris. Conservation Genetics 5, 231-245.

Vergeer, P., Rengelink, R., Copal, A., Ouborg, N.J., 2003. The interacting effects of genetic variation, habitat quality and population size on performance of Succisa pratensis. Journal of Ecology 91, 18-26.

Ward, M., Johnson, S.D., 2005. Pollen limitation and demographic structure in small fragmented populations of Brunsvigia radulosa (Amaryllidaceae). OIKOS 108, 253-262.

White, G.M., Boshier, D.H., Powell, W., 1999. Genetic variation within a fragmented population of Swietenia humilis Zucc. Molecular Ecology 8, 1899-1909.

White, G.M., Boshier, D.H., Powell, W., 2002. Increased pollen flow counteracts fragmentation in a tropical dry forest: an example from Swietenia humilis Zuccarini. Proceedings of the National Academy of Sciences of the United States of America 99, 20382042.

Whitney, K.D., 2002. Dispersal for distance? Acacia ligulata seeds and meat ants Iridomyrmex viridiaeneus. Austral Ecology 27, 589-595.

Willi, Y., van Buskirk, J., Fischer, M., 2005. A threefold genetic allee effect: population size affects cross-compatibility, inbreeding depression and drift loan in the self-incompatible Ranunculus reptans. Genetics 169, 2255-2265.

Williams, J., 2000. Managing the bush: recent research findings from the EA/LWRRDC national remnant vegetation R\&D program. In: National Research and Development Program on Rehabilitation, Management and Conservation of Remnant Vegetation. ed. Environment Australia. Land and Water Resources Research and Development Corporation, Canberra.

Yates, C.J., Broadhurst, L.M., 2002. Assessing limitations on population growth in two critically endangered Acacia taxa. Biological Conservation 108, 13-26.

Yates, C.J., Elliot, C., Byrne, M., Coates, D.J., Fairman, R., 2007. Seed production, germinability and seedling growth for a shrub in fragments of species rich kwongon in south-west Australia. Biological Conservation 136, 306-314.

Young, A., Broadhurst, L., Coates, D., Byrne, M., Yates, C., Elliot, C., Field, D., Gage, C., Hobbs, R., 2005. Genetic and Ecological Viability of Plant Populations in Remnant Vegetation. Land and Water Australia, Canberra. 120.

Young, A.G., Brown, A.H.D., Murray, B.G., Thrall, P.H., Miller, C., 2000. Genetic erosion, restricted mating and reduced viability in fragmented populations of the endangered grassland herb Rutidosis leptorrhynchoides. In: Young, A.G., Clarke, G.M. (Eds.), Genetics Demography and Viability of Fragmented Populations. Cambridge University Press, Cambridge, pp. 335359.

Young, A.G., Brown, A.H.D., Zich, F.A., 1999. Genetic structure of fragmented populations of the endangered daisy Rutidosis leptorrhynchoides. Conservation Genetics 13, 256-265. 